\title{
Ecological catalysis and phytoextraction: symbiosis for future
}

\author{
Vincent Escande ${ }^{\mathrm{a}}$, Laetitia Garoux ${ }^{\mathrm{b}}$, Claire Grison ${ }^{\mathrm{a}}$, Yann Thillier ${ }^{\mathrm{c}}$, Françoise \\ Debart $^{\mathrm{c}}$, Jean-Jacques Vasseur ${ }^{\mathrm{c}}$, Clothilde Boulanger ${ }^{\mathrm{b}}$ and Claude Grison ${ }^{\mathrm{a} *}$
}

${ }^{\text {a }}$ Centre d'Ecologie Fonctionnelle et Evolutive, UMR CNRS-UM2 5175, 1919 route de Mende, 34293

Montpellier cedex 5 (France) and Agence de l'Environnement et de la Maîtrise de l'Energie

(ADEME), 20 avenue du Grésillé, BP 90406, 49004 Angers cedex 01 (France)

*Corresponding author at : Centre d'Ecologie Fonctionnelle et Evolutive, UMR CNRS-UM2 5175, 1919 route de Mende, 34293 Montpellier cedex 5 (France)

Tel. : +33 467613316 ; Fax : +33 467412138 ; E-mail: claude.grison@cefe.cnrs.fr

${ }^{\mathrm{b}}$ Institut Jean Lamour, UMR 7198, Université de Lorraine, CNRS, 1 bd Arago, CP87811, 57078 Metz cedex (France)

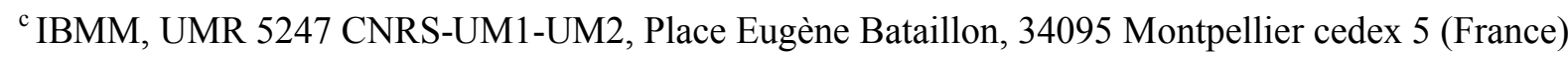

\begin{abstract}
Metallophyte plants derived from phytoextraction are used as starting materials to prepare novel polymetallic catalysts. Polymetallic catalyst activity is used in many Lewis acid catalyzed reactions according to the polymetallic catalyst preparation. The synergetic catalysis of these systems leads to efficient syntheses of complex biomolecules such as dihydropyrimidinone, 5'-capped DNA and RNA, and glycosyl aminoacid. These new polymetallic catalysts also bring new possibilities in Green Catalysis, that we named "Ecological Catalysis".
\end{abstract}

\section{KEYWORDS}

sustainable chemistry, ecological catalysis, heterogeneous catalysis, biomolecules, phytoextraction

\section{Introduction}

\subsection{Ecological Catalysis in sustainable chemistry context}

In recent years, Organic Chemistry has focused on environment-friendly processes. The "Green Chemistry" concept is an interesting approach to reduce negative environmental impacts of organic synthesis. Modern chemistry requires chemical processes designed to reduce waste production; which facilitate efficient reuse and recycling; and which use starting material derived from renewable resources or from abundant wastes.[1-3] Consequently, chemical engineering is now showing a considerable interest in catalytic processes. Amongst other approaches, chemo- and bio-catalysis represent particularly current and relevant topics in research and 
development of new catalytic processes. In this context, metal heterogeneous catalysis, nanocatalysis, electrocatalysis, photocatalysis or biocatalysis are key technologies to achieve green synthesis.[4-7] Catalytic synthetic methodologies approach now sustainability but don't solve environmental problems yet. That is why we wanted to achieve the synthesis of molecules of interest with raw material, derived from restoration processes of polluted sites, as new catalysts. The generalization of this methodology should thus encourage the development of restoration programs of polluted sites, thanks to the economic interest of the molecules produced according to this new approach in Catalysis.

This issue is therefore devoted to the development of a new concept of plant-based polymetallic catalysis, that we call "Ecological Catalysis". The concept combines the catalytic green chemistry field and the important implications of a solution to metallic element persistence and bio-accumulation.

\subsection{Connecting phytoextraction of trace metals, environmental opportunities and innovative plant- based chemistry}

Trace metals (TM) in soils present major environmental problems worldwide. Metal-hyperaccumulating plants, or metallophytes, extract TM from contaminated soils and concentrate them in their shoots. Their discovery was a wonderful opportunity to remove TM from the environment. Exploring the utility of these plants had led to the development of phytoextraction. Today, using plants to clean up the environment is achievable on a large-scale, cost-effective and has good public acceptance. The main disadvantage is the lack of real economic opportunities.[8-11] Therefore, we demonstrated that metallophytes could be the basis of a novel, plant-inspired, metallo-catalytic platform for green synthesis of molecules of biological interest.

Zinc hyperaccumulating plants are an attractive resource for new chemical perspectives.[12, 13] For example, Noccaea caerulescens and Anthyllis vulneraria, are able to concentrate about $120000 \mathrm{ppm}$ of $\mathrm{Zn}^{\mathrm{II}}$ in calcined shoots.[14] They represent fascinating models for the preparation of ecological catalysts.[14-16]

\section{Experimental}

\subsection{Preparation of catalytic extracts from metallophyte species}

Leaves were harvested before flowering, air-dried and crushed. The obtained solid $(150 \mathrm{~g})$ was calcined at 400 ${ }^{\circ} \mathrm{C}$ for $5 \mathrm{~h}$ and the resulting powder $(24 \mathrm{~g})$ was added to $1 \mathrm{~L}$ of a solution of $5 \mathrm{M} \mathrm{HCl}$ solution. The solution was heated at $60{ }^{\circ} \mathrm{C}$ and stirred for $2 \mathrm{~h}$. The reaction mixture was filtered on celite. The resulting solutions, composed of different metal chlorides, were then concentrated under vacuum. Dry residues were either used crude or partially purified in order to decrease the concentration of alkali and alkaline earth metals in the catalytic solid. With Zn hyperaccumulating metallophytes ( $N$. caerulescens and A. vulneraria), Amberlite IRA 400 ion exchange resin was used for adsorption of $\mathrm{Zn}{ }^{\text {II }}$ on the resin, and elution of alkali and alkaline earth cations (fraction 1). Treatment with $0.5 \mathrm{M} \mathrm{HCl}$ eliminated a part of $\mathrm{Fe}$ "III fixed on the resin before the elution of heavy metals $\mathrm{Zn}$, $, \mathrm{Cd}^{\mathrm{II}}, \mathrm{Pb}^{\text {II }}$ (fraction 2) with $0.005 \mathrm{M} \mathrm{HCl}$. When mentioned, a mixture of these plant-derived Lewis acids and montmorillonite $\mathrm{K} 10$ was prepared by co-grinding with mortar and pestle, at room temperature. $2.0 \mathrm{~g}$ of montmorillonite $\mathrm{K} 10$ were mixed with the plant-derived Lewis acids (amount corresponding to $1.1 \mathrm{mmol}$ of metal of interest $/ \mathrm{g}$ of support). This mixture was activated at $100^{\circ} \mathrm{C}$ for $15 \mathrm{~min}$ before use.

\subsection{Characterization of catalytic extracts from metallophyte species}

Chemical analysis of the plant extract samples after calcinations $\left(400^{\circ} \mathrm{C}\right.$ for $\left.3 \mathrm{~h}\right)$ was performed by X-Ray Fluorescence spectrometry (XRF) using a BRUKER AXS S4 Explorer wavelength-dispersive spectrometer. The quantitative analysis of major and expected elements was performed on beaded samples for overcoming problems of particle size variation as well as mineralogy effects: the powdered sample is mixed with a $\mathrm{Li}_{2} \mathrm{~B}_{4} \mathrm{O}_{7}$ 
flux with a flux / sample ratio equal to 8 , heated in a crucible between $400-600{ }^{\circ} \mathrm{C}$, then cast in a platinum dish to produce a homogeneous glass-like bead.

ICP-MS was used to confirm the composition of the various plant extracts obtained. ICP-MS analyses were performed using the Metal Analysis of total dissolved solutes in water. The samples were acidified with nitric acid $2.5 \%$ and stirred for $30 \mathrm{~min}$. The digestates were diluted to 0.005 g.L ${ }^{-1}$. Three blanks are recorded for each step of the digestion and dilution procedure on a HR-ICP-MS Thermo Scientific Element XR.

$\mathrm{X}$-ray diffraction (XRD) data measurements on the samples dried at $110^{\circ} \mathrm{C}$ for 2 hours were performed by using a BRUKER diffractometer (D8 advance, with a $\mathrm{Cu} \mathrm{K} \alpha$ radiation $\lambda=1.54086 \AA$ ) equipped with a Lynxeyes detector.

FTIR measurements were carried out using pyridine as probe molecule. The samples were pressed into wafers $(8$ mg.cm $\left.{ }^{-2}\right)$ and activated in the IR cell under flowing air $\left(1 \mathrm{~cm}^{3} \cdot \mathrm{s}^{-1}\right)$ at $400^{\circ} \mathrm{C}$ for $10 \mathrm{~h}$ and then under vacuum $\left(10^{-3}\right.$ $\mathrm{Pa}$ ) for $1 \mathrm{~h}$. A PerkinElmer Spectrum $100 \mathrm{FT}$-IR spectrometer was used for recording the spectra. Excess gaseous pyridine was adsorbed, then the samples were degassed for 15 minutes at $25^{\circ} \mathrm{C}\left(10^{-3} \mathrm{~Pa}\right)$ and a first spectrum was recorded. The samples were then degassed for 15 minutes at $150^{\circ} \mathrm{C}\left(10^{-3} \mathrm{~Pa}\right)$ to eliminate the physisorbed pyridine and a second spectrum was recorded.

\subsection{Use of catalytic extracts (Green Lewis Acid Catalysts) in organic synthesis}

\subsubsection{Chemicals}

Reagents and solvents were purchased from Aldrich, excepted guanosine-5'-diphosphate (GDP) salts, purchased from Jena Bioscience and 1,8-diazabicyclo[5.4.0]undec-7-ene purchased form Acros Organics. Reagents were used without further purification unless otherwise noted. Pyridine, acetonitrile, triethylamine, butylamine and trin-butylamine were distilled on calcium hydride. All reactions were performed under argon (or nitrogen) and stirring unless otherwise noted. When needed, glassware was dried overnight in an oven $\left(\mathrm{T}>100^{\circ} \mathrm{C}\right)$.

\subsubsection{Purification and analysis of reaction products}

Flash column chromatography was performed using Chromagel Carlo Erba Reactifs SDS silica 60 A CC 35-70 $\mu \mathrm{m}$. Reactions were monitored using Merck Kieselgel 60 F254 aluminium. TLC's were visualized by UV fluorescence $\left(254 \mathrm{~nm}\right.$ ) then one of the following: $\mathrm{KMnO}_{4}$, ninhydrine, phosphomolybdic acid solution, phosphotungstic acid solution.

Analytical and semi-preparative high performance liquid chromatographies were performed on a Dionex DX 600 HPLC system or a Dionex U 3000 HPLC system equipped with anion-exchange DNAPac PA 100 columns (4 x $250 \mathrm{~mm}$ for analysis or $9 \times 250 \mathrm{~mm}$ for purification, Dionex). The following HPLC solvent systems were used: $5 \% \mathrm{CH}_{3} \mathrm{CN}$ in $25 \mathrm{mM}$ Tris- $\mathrm{HCl}$ buffer, $\mathrm{pH} 8$ (buffer A) and $5 \% \mathrm{CH}_{3} \mathrm{CN}$ containing $400 \mathrm{mM} \mathrm{NaClO}_{4}$ in $25 \mathrm{mM}$ Tris- $\mathrm{HCl}$ buffer, $\mathrm{pH} 8$ (buffer B). Flow rates were $1.5 \mathrm{~mL} \cdot \mathrm{min}^{-1}$ and $5 \mathrm{~mL} \cdot \mathrm{min}^{-1}$ for analysis and semipreparative purposes, respectively.

NMR spectra were recorded on a Brüker Avance 300 spectrometer at room temperature, ${ }^{1} \mathrm{H}$ frequency is at 300 $\mathrm{MHz},{ }^{13} \mathrm{C}$ frequency is at $75 \mathrm{MHz}$. IR spectra were recorded on a PerkinElmer Spectrum $100 \mathrm{FT}-\mathrm{IR}$ spectrometer, in ATR mode. Mass spectra were determined with a LC/MS Waters 3695 Separation module, Micromass ZQ 2000 by electrospray ionization (ESI positive or negative). MALDI-TOF mass spectra were recorded on a Voyager-DE spectrometer (Perseptive Biosystems, USA) using a 10:1 (m/m) mixture of 2,4,6trihydroxyacetophenone/ammonium citrate as a saturated solution in acetonitrile/water $(1: 1, \mathrm{v} / \mathrm{v})$ for the matrix. 


\subsubsection{Representative procedure for the synthesis of dihydropyrimidinones with Green Lewis Acid}

Catalyst: synthesis of 5-ethoxycarbonyl-6-methyl-4-isobutyl-3,4-dihydropyrimidin-2(1H)-one (4)

A solution of ethyl acetoacetate $\mathbf{2}$ (781 mg, $6.0 \mathrm{mmol})$, 3-methylbutyraldehyde $\mathbf{3}(345 \mathrm{mg}, 4.0 \mathrm{mmol})$ and urea $\mathbf{1}$ ( $360 \mathrm{mg}, 6.0 \mathrm{mmol})$ in $95 \%$ ethanol $(10 \mathrm{~mL}$ ) was heated to reflux in the presence of montmorillonite $\mathrm{K} 10$ supported crude Green Lewis Acid Catalyst derived from Zn hyperaccumulator plants (1650 mg, amount corresponding to $1.0 \mathrm{mmol}$ of zinc following ICP-MS dosing) with 3 drops of hydrochloric acid (12 M) for $5 \mathrm{~h}$ (TLC). The reaction mixture was filtered in order to remove the catalyst, which can be reactivated by heating, after been washed with ethanol $\left(3 \times 10 \mathrm{~mL}\right.$ then $\left.150^{\circ} \mathrm{C}, 5 \mathrm{~h}\right)$. The solution was poured into crushed ice $(20 \mathrm{~g})$ and stirred for $20 \mathrm{~min}$. The solid separated was filtered under suction, washed with cold water $(30 \mathrm{~mL})$ and recrystallized from hot ethanol, affording pure product $(870 \mathrm{mg}, 91 \%), \mathbf{m p ~} 179-181{ }^{\circ} \mathrm{C}$ (lit. $\left.178-180{ }^{\circ} \mathrm{C}\right)$; IR $3229,3107,2951,1698,1649 \mathrm{~cm}^{-1} ;{ }^{1} \mathbf{H}$ NMR (DMSO-d $\left.6,300 \mathrm{MHz}\right) \delta: 8.92(\mathrm{~s}, 1 \mathrm{H}, \mathrm{NH}), 7.39(\mathrm{~s}, 1 \mathrm{H}, \mathrm{NH})$, 3.99-4.12 (m, 3H, $\mathrm{H} 4$ and $\left.\mathrm{OCH}_{2} \mathrm{Me}\right), 2.16$ (s, 3H, C(6)-Me), $1.70\left(\mathrm{~m}, 1 \mathrm{H}, \mathrm{CH}_{2} \mathrm{CHMe}_{2}\right), 1.38(\mathrm{~m}, 1 \mathrm{H}$, $\mathrm{CH}_{2} \mathrm{CHMe}_{2}$ ), 1.19 (t, 3H, $\left.\mathrm{OCH}_{2} \mathrm{Me},{ }^{3} J=7.2 \mathrm{~Hz}\right), 1.10$ (m, $1 \mathrm{H}, \mathrm{CH}_{2} \mathrm{CHMe}_{2}$ ), 0.86 (d, 6H, $\mathrm{CH}_{2} \mathrm{CHMe}_{2},{ }^{3} J=6.6 \mathrm{~Hz}$ ). ${ }^{13} \mathbf{C}$ NMR (DMSO-d 6 , $\left.75 \mathrm{MHz}\right) \delta: 165.2,152.8,148.1,100.3,59.0,48.1,46.0,23.6,22.8,21.3,17.6,14.1$. MS $\left(\mathrm{EI}^{+}\right)$calcd for $\mathrm{C}_{12} \mathrm{H}_{20} \mathrm{~N}_{2} \mathrm{O}_{3}[\mathrm{M}]^{+} 240.2$, found $241.2[\mathrm{M}+1]^{+}$.

\subsubsection{Representative procedure for the selective deprotection of methyl ester: synthesis of 6,7-} dideoxy-1,2:3,4-di-O-isopropyldine-7-[(9-flurenylmethoxycarbonyl)amino]-D-glycero- $\alpha$-D-galactooctopyranuronic acid (9)

A solution of $0.87 \mathrm{~mL}$ of $\mathrm{NaOH} 1 \mathrm{M}(0.9 \mathrm{mmol}, 1.2$ eq. $)$ is added at room temperature to 1.8 eq of $\mathrm{Ca}$ (II) from fraction 1 dissolved in $16 \mathrm{~mL}$ of a mixture of isopropanol/water $7 / 3(\mathrm{v} / \mathrm{v})$. After $5 \mathrm{~min}$ of stirring, $0.4 \mathrm{~g}$ of methyl ester 8 ( $7.2 \mathrm{mmol}, 1$ eq.) is slowly added. The reaction mixture is stirred for $3 \mathrm{~h} 30$ then diluted by addition of 10 $\mathrm{mL}$ of diethyl ether. $\mathrm{pH}$ is adjusted to 4 by addition of hydrochloric acid solution $(1 \mathrm{M})$ then the aqueous layer is extracted with diethyl ether. Organic layers are combined, dried with $\mathrm{MgSO}_{4}$, filtrated and evaporated under reduced pressure. The obtained residue is purified by column chromatography on silica gel (hexane/EtOAc 1/1 $\mathrm{v} / \mathrm{v})$. A white solid is obtained with $82 \%$ yield. $\mathbf{R f}=0.5(\mathrm{EtOH} / \mathrm{EtOAc} 1 / 9 \mathrm{v} / \mathrm{v}) ; \mathbf{I R} 3450,1700 \mathrm{~cm}^{-1} ;{ }^{1} \mathbf{H}$ NMR $\left(\mathrm{CDCl}_{3}, 300 \mathrm{MHz}\right) \delta: 7.74\left(\mathrm{~d}, 2 \mathrm{H},{ }^{3} J=7.4 \mathrm{~Hz}\right), 7.58\left(\mathrm{~d}, 2 \mathrm{H},{ }^{3} J=7.0 \mathrm{~Hz}\right), 7.41-7.24(\mathrm{~m}, 4 \mathrm{H}), 5.74\left(\mathrm{~d}, 1 \mathrm{H}, \mathrm{NH},{ }^{3} J\right.$ $=7.6 \mathrm{~Hz}), 5.49\left(\mathrm{~d}, 1 \mathrm{H},{ }^{3} J=5.2 \mathrm{~Hz}\right), 4.58\left(\mathrm{dd}, 1 \mathrm{H},{ }^{3} J=5.2 \mathrm{~Hz},{ }^{3} J=2.3 \mathrm{~Hz}\right), 4.24-4.17(\mathrm{~m}, 1 \mathrm{H}), 4.16-4.08(\mathrm{~m}, 1 \mathrm{H}), 3.97-$ $3.85(\mathrm{~m}, 1 \mathrm{H}), 2.48-2.31(\mathrm{~m}, 1 \mathrm{H}), 2.17-2.09(\mathrm{~m}, 1 \mathrm{H}), 1.44(\mathrm{~s}, 3 \mathrm{H}), 1.43(\mathrm{~s}, 3 \mathrm{H}), 1.32(\mathrm{~s}, 3 \mathrm{H}), 1.28(\mathrm{~s}, 3 \mathrm{H}) .{ }^{13} \mathbf{C}$ NMR (DMSO-d $\left.\mathrm{d}_{6}, 75 \mathrm{MHz}\right) \delta$ : 176.3, 156.3, 143.3, 141.3, 127.7, 127.1, 125.1, 120.0, 109.6, 108.8, 94.5, 72.6, 70.4, 67.2, 64.5, 51.2 , 47.2, 31.6, 25.9, 25.7, 24.9, 24.6. $\mathbf{M S}\left(\mathrm{EI}^{+}\right)$calcd for $\mathrm{C}_{29} \mathrm{H}_{33} \mathrm{NO}_{9}[\mathrm{M}]^{+} 539.2$, found 540.2 $[\mathrm{M}+1]^{+}$.

2.3.5. Representative procedure for the coupling of solid-supported $T_{6}$ phosphoro-imidazolidate with GDP: synthesis of 5'-guanosyl triphosphate hexa-2'-deoxythymidylate (Gppp $\left.T_{6}\right)$ (12)

\subsubsection{Capping reaction with GDP (10)}

In a dry $2 \mathrm{~mL}$ microcentifuge tube (Costar), bis (tri-n-butylammonium) GDP 10 (103 mg, $0.14 \mathrm{mmol}$ ) and the correct amount of freshly dehydrated catalytic extracts $([\mathrm{Zn}]=0.4 \mu \mathrm{M})$ were mixed in anhydrous DMF $(0.5$ $\mathrm{mL}$ ). The tube was closed and the mixture was vortexed for 5 minutes on a Top-Mix 1118 (Fischerbrand) and centrifuged in a tabletop centrifuge (Sigma 1-13) at 6000 min-1 for 30 seconds. This operation was repeated twice. The supernatant was taken using a glass syringe filled with 3 beads of $4 \AA$ molecular sieves. Using another syringe, the solution was applied to the column containing the solid-supported 5'-phosphoroimidazolidate oligonucleotide 11 (prepared following a method described by Thillier and coworkers[17]), and left to react for $18 \mathrm{~h}$ at $30^{\circ} \mathrm{C}$. The solution was removed and the support was washed with water $(2 \times 2 \mathrm{~mL})$, then with a $0.1 \mathrm{M}$ aqueous solution of EDTA (pH 7, $2 \times 2 \mathrm{~mL})$, and dry $\mathrm{CH}_{3} \mathrm{CN}(4 \times 2 \mathrm{~mL})$. Finally the column was dried by blowing argon through it during $1 \mathrm{~min}$. 


\subsubsection{Deprotection and release of Gpppt $_{6}(\mathbf{1 2})$}

The solid-supported GpppT $6 \mathbf{1 2}$ was deprotected and released from the support as follows: firstly, a $1 \mathrm{M}$ solution of 1,8-diazadicyclo-[5.4.0]undec-7-ene (DBU) in anhydrous $\mathrm{CH}_{3} \mathrm{CN}$ was applied to the column for $3 \mathrm{~min}$. Then the solution was removed and the solid-support was washed with anhydrous $\mathrm{CH}_{3} \mathrm{CN}$. The support was dried by a 1 min flush with argon. Secondly, a $30 \%$ aqueous ammonia solution was applied to the column in three batches $(1.5 \mathrm{~mL}, 1 \mathrm{~mL}, 0.5 \mathrm{~mL})$ for $30 \mathrm{~min}$ each. The three ammonia fractions were collected in a $4 \mathrm{~mL}$ screw-capped glass vial and were left to react at room temperature for $1.5 \mathrm{~h}$. The fully deprotected oligonucleotides were transferred to $50 \mathrm{~mL}$ round-bottomed flasks and isopropylamine ( $15 \%$ of total volume: $0.45 \mathrm{~mL}$ ) was added only to the solutions of $\mathrm{GpppT}_{6} \mathbf{1 2}$. Then the mixtures were evaporated under reduced pressure with a bath at $30^{\circ} \mathrm{C}$ maximum until the volumes were reduced to $0.3 \mathrm{~mL}$. The mixtures were coevaporated three times with $1 \mathrm{~mL}$ of water following the same protocol. The residues were redissolved in water $(1.5 \mathrm{~mL}$ divided in three portions for flask rinse: $0.8 \mathrm{~mL}, 0.4 \mathrm{~mL}, 0.3 \mathrm{~mL}$ ) and transferred to $2 \mathrm{~mL}$ Eppendorf-vials then lyophilized from water. The crude $\mathrm{GpppT}_{6}$ was analyzed on a Dionex DX 600 HPLC system monitored at $260 \mathrm{~nm}$ with a $0 \%-30 \%$ linear gradient of buffer $\mathrm{B}\left(5 \% \mathrm{CH}_{3} \mathrm{CN}\right.$ containing $400 \mathrm{mM} \mathrm{NaClO}_{4}$ in $25 \mathrm{mM}$ Tris- $\mathrm{HCl}$ buffer, $\mathrm{pH}$ ) $)$ in buffer $\mathrm{A}(5 \%$ $\mathrm{CH}_{3} \mathrm{CN}$ in $25 \mathrm{mM}$ Tris-HCl buffer, $\mathrm{pH}$ 8). MALDI-TOF characterization in negative mode: calcd for $\mathrm{C}_{70} \mathrm{H}_{93} \mathrm{~N}_{17} \mathrm{O}_{57} \mathrm{P}_{8}[\mathrm{M}-\mathrm{H}]^{-} 2267.35$, found $2267.25[\mathrm{M}-\mathrm{H}]^{-}$. 


\section{Results and discussion}

\subsection{Catalysts characterization by XRF and XRD analysis}

The first step of the process was the thermic treatment of leaves at $400^{\circ} \mathrm{C}$, followed by the addition of $\mathrm{HCl}(1 \mathrm{M})$ and the concentration of the solution, which led to an unusual mixture of metallic chlorides and oxides. The potential of zinc hyperaccumulating plants for Ecological Catalysis was based on the total mineral composition of contaminated biomass. $\mathrm{Zn}^{\mathrm{II}}, \mathrm{Cd}^{\mathrm{II}}$ and $\mathrm{Pb}^{\mathrm{II}}$ were due to the $\mathrm{TM}$ hyperaccumulation ability of metallophyte plants. $\mathrm{Na}^{\mathrm{I}}, \mathrm{K}^{\mathrm{I}}, \mathrm{Ca}^{\mathrm{II}}, \mathrm{Mg}^{\mathrm{II}}, \mathrm{Fe}^{\mathrm{III}}$ were also present as they are essential for plant growth.

The challenge was to develop ecological chemical methodologies, where each metallic fraction was useful and presented catalytic properties in organic synthesis. Hence, we investigated a partial separation of metallic derivatives through the ion exchange separation. It was found to be a solventless and efficient process. The use of Amberlite IRA 400 resulted in the preparation of three very active catalytic systems from a single batch of biomass residues: the crude mixture $\mathrm{Zn}^{\mathrm{II}}-\mathrm{Fe}^{\mathrm{III}}-\mathrm{Al}^{\mathrm{III}}-\mathrm{Cd}^{\mathrm{II}}-\mathrm{Pb}^{\mathrm{II}}-\mathrm{Mg}^{\mathrm{II}}-\mathrm{Ca}^{\mathrm{II}}$; a solid highly enriched in $\mathrm{Zn}^{\mathrm{II}}$; and a solid highly concentrated in $\mathrm{Ca}^{\mathrm{II}}$. X-ray fluorescence (XRF) was used to determine the chemical composition analysis of all fractions from the plant extracts obtained (Table 1).

Table. 1. Composition of obtained plant extract for Ecological Catalysis

\begin{tabular}{|c|c|c|c|c|c|c|c|c|c|c|c|}
\hline mass percent composition & $\mathrm{Na}$ & $\mathrm{K}$ & $\mathrm{Mg}$ & $\mathrm{Ca}$ & $\mathrm{Fe}$ & $\mathrm{Zn}$ & $\mathrm{Cd}$ & $\mathrm{Al}$ & $\mathrm{Pb}$ & $\mathrm{O}$ & $\mathrm{Cl}$ \\
\hline $\begin{array}{l}\text { A.vulneraria and } \\
\text { N.caerulescens crude extract }\end{array}$ & 1,72 & 5,72 & 1,6 & 10,3 & 2,75 & 6,74 & 0,19 & 1,5 & 0,44 & 15,97 & 42,27 \\
\hline $\begin{array}{l}\mathrm{Ca}^{\mathrm{II}} \text { enriched extract: } \\
\text { fraction } 1\end{array}$ & 0,57 & 7,44 & 5,56 & 14,3 & 0,11 & 0,04 & - & 0,69 & 0,49 & 14,44 & 53,09 \\
\hline $\begin{array}{l}\mathrm{Zn}^{\mathrm{II}} \text { enriched extract: } \\
\text { fraction } 2\end{array}$ & 5,8 & 0,1 & 0,2 & 0,36 & 4,26 & 33,02 & 0,13 & - & 0,49 & 13,86 & 37,8 \\
\hline
\end{tabular}

The XRF data were confirmed by inductively coupled plasma mass spectroscopy (ICP-MS). As indicated in Table 1, data from the crude extract confirmed the exceptional capacity of Noccaea caerulescens and Anthyllis vulneraria for $\mathrm{Zn}$ hyperaccumulation. The extract contained high amounts of transition metals: $6.74 \%$ of $\mathrm{Zn}$, and $2.75 \%$ of $\mathrm{Fe}^{\mathrm{III}}$, which are two powerful Lewis acids. This is interesting since several Lewis acids were gathered in one extract, a potential ecological catalyst. A significant amount of $\mathrm{Ca}^{\mathrm{II}}(10.30 \%)$ should also be noted. Simple calculations revealed that solutions could not be considered to simply contain a hydrated mixture of $\mathrm{ZnCl}_{2}, \mathrm{CaCl}_{2}$ and $\mathrm{FeCl}_{3}$. A liquid-liquid extraction with the trioctylamine (TOA) / toluene system had been employed to identify soluble species. A number of salts containing $\left[\mathrm{ZnCl}_{3}\right]^{-}$and $\left[\mathrm{ZnCl}_{4}\right]^{2-},\left[\mathrm{ZnCl}_{2}\left(\mathrm{PO}_{4}\right) \mathrm{FeCl}_{4}\right]^{]}$ anions were isolated after extraction and analysis by LC MS.

XRD pattern was performed for crude extract (Figure 1) and for each fraction separated with Amberlite resin (Figures 2 and 3). The main diffraction peaks of the predominant minerals are shown for reference purposes. Table 2 summarizes these data.

The X-ray diffraction of $\mathrm{Ca}^{\mathrm{II}}$-enriched extract (Fraction 1) revealed a mixture of calcium-magnesium salt $\left(\mathrm{CaMg}_{2} \mathrm{Cl}_{6}\left(\mathrm{H}_{2} 0\right)_{12}, \mathrm{CaMg}\left(\mathrm{CO}_{3}\right)_{2}\right), \mathrm{KCaCl}_{3}$ and $\mathrm{CaCO}_{3}$. The $\mathrm{Zn}^{\mathrm{II}}$-enriched extract (Fraction 2) corresponded to an amorphous, hygroscopic and even deliquescent mixture similar to $\mathrm{ZnCl}_{2}$. The mineral analysis clearly revealed that $\mathrm{Zn}{ }^{\mathrm{II}}$ was the major cation (33\%), which is also the major Lewis acid and therefore a potential efficient catalyst. As expected $\mathrm{Ca}^{\mathrm{II}}$ salts were eliminated. A treatment with dioxane[18] allowed the formation of crystalline species. According to obtained XRD data, two crystal structures of $\mathrm{ZnCl}_{2}$ have been obtained; the monoclinic structure, normally observed at room temperature, and a tetragonal structure (form $\beta$ ) usually 
observed above $390 \mathrm{~K}$. As observed in XRD pattern (figure 3), the potassium zinc tetrachloride detected in the crude extract was found in the fraction 2 . The presence of $\mathrm{ZnCl}_{2}$ probably indicated that $\mathrm{K}_{2} \mathrm{ZnCl}_{4}$ was converted into more stable $\mathrm{ZnCl}_{2}, \mathrm{KCl}$ and $\mathrm{KClO}_{3}$ species.

The source of chlorate (fraction 2 treated with dioxan) and perchlorates (fraction 1 and crude extract supported) was not clear. The hypothesis of $\mathrm{K}_{2} \mathrm{ZnCl}_{4}$ decomposition and subsequent oxidation was not satisfactory. This oxidation was not explained by the redox properties of present cations. The oxyanion chlorides didn't exist in the crude fraction (not supported). Thus, they didn't derive from plants. Probably, the oxidation of chloride into chlorate and perchlorate occurred during the purification and the preparation of the supported extract.

Thus, the ecological catalysts had a complex and an original composition. It brings new perspectives such as the formation and the stabilization of $\left[\mathrm{ZnCl}_{4}\right]^{2-}$ and $\left[\mathrm{ZnCl}_{3}\right]^{-}$, which have provided conflicting results and which are rarely observed in solution.[19] According to their $\mathrm{Kd}$, they constitute masked form of $\mathrm{ZnCl}_{2}$ in solution. The association of these species with other metallic cations was also an exciting and unusual situation. This novel polymetallic composition should be investigated in catalyzed organic synthesis.

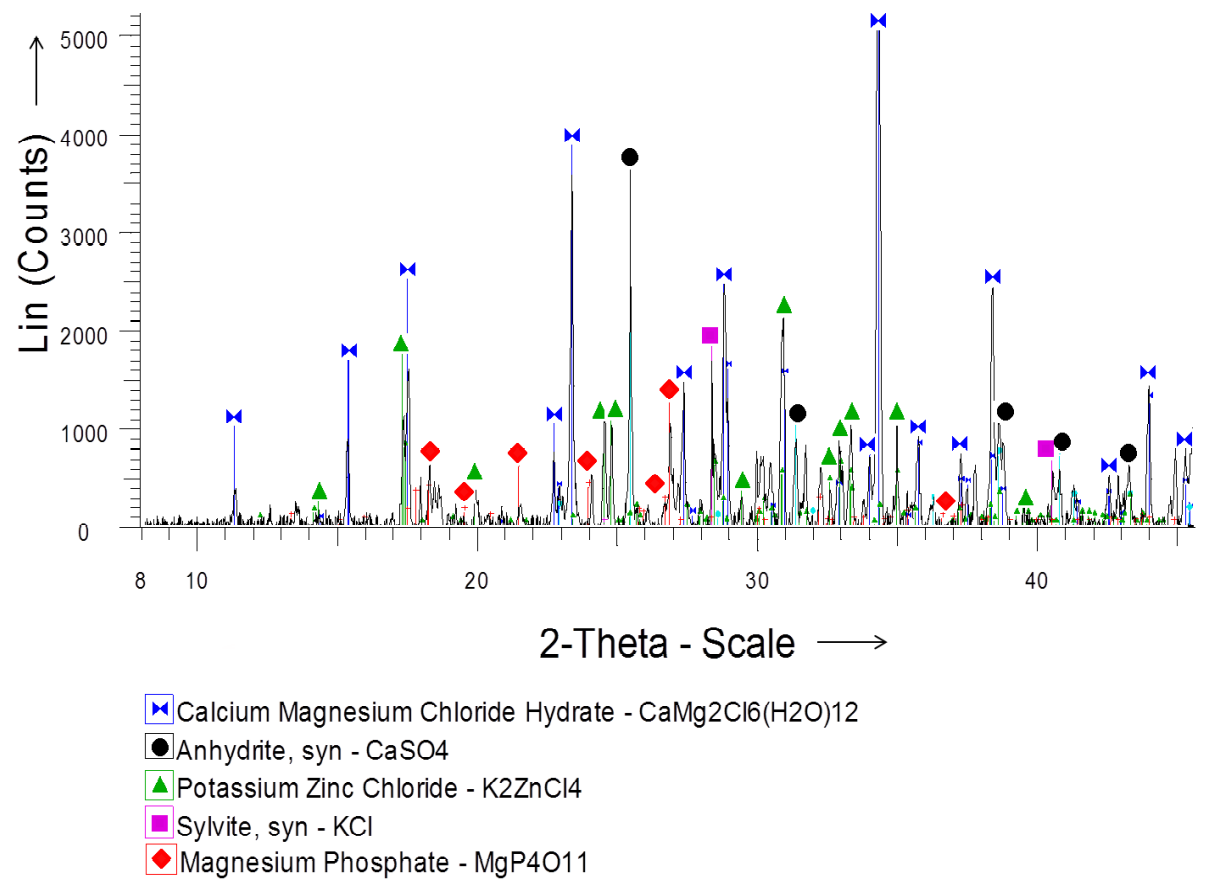

Fig. 1. XRD pattern of crude extract

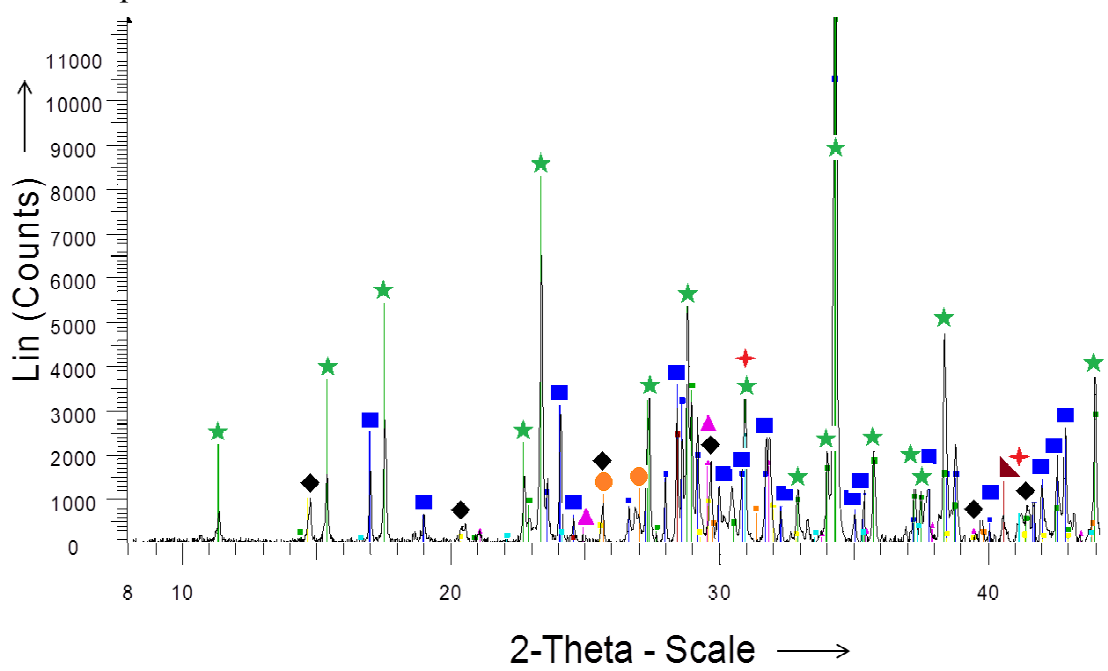

Chlorocalcite, syn [NR] - $\mathrm{KCaCl} 3$

$\star$ Calcium Magnesium Chloride Hydrate - CaMg2Cl6(H2O)12

Calcium Sulfate - $\mathrm{Ca}(\mathrm{SO} 4)$

$\triangle$ Calcium Carbonate - $\mathrm{CaCO} 3$

Sylvite, syn - $\mathrm{KCl}$

- Calcium Chlorate - $\mathrm{Ca}(\mathrm{ClO} 4)_{2}$

+ Dolomite - $\mathrm{CaMg}(\mathrm{CO} 3) 2$ 
Fig. 2. XRD pattern of fraction 1

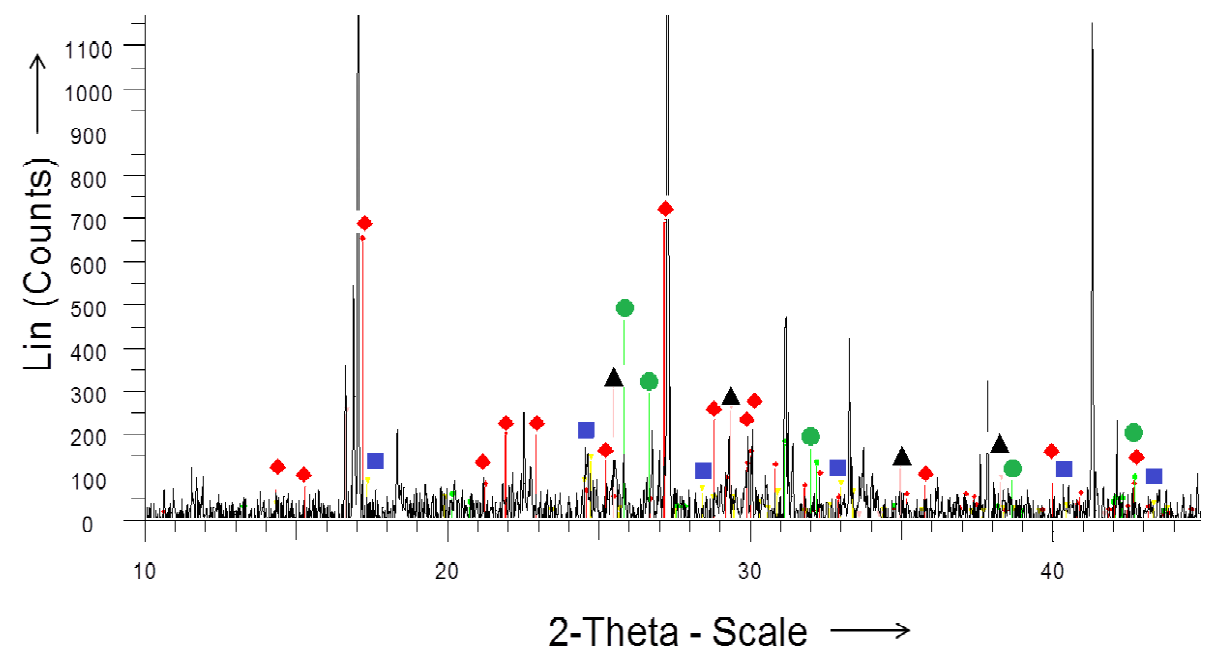

$\square$ Potassium Zinc Chloride - $\mathrm{K} 2 \mathrm{ZnCl} 4$

-Zinc Chloride - ZnCl2 - (monoclinic)

Potassium Chlorate - $\mathrm{KClO} 3$

$\Delta$ Zinc Chloride - $\mathrm{ZnCl}$ - (tetragonal)

Fig.3. XRD pattern of fraction 2 after treatment with dioxane

Table 2. XRD pattern of crude extract and eluted fractions

\begin{tabular}{|c|c|c|}
\hline Fraction & Mineral & $\begin{array}{l}\text { Formula } \\
\text { (simplified) }\end{array}$ \\
\hline \multirow[t]{5}{*}{ Crude } & $\begin{array}{l}\text { Calcium magnesium } \\
\text { chloride hydrate }\end{array}$ & $\mathrm{CaMg}_{2} \mathrm{Cl}_{6}\left(\mathrm{H}_{2} \mathrm{O}\right)_{12}$ \\
\hline & Anhydrite, syn & $\mathrm{CaSO}_{4}$ \\
\hline & $\begin{array}{l}\text { Potassium zinc } \\
\text { tetrachloride }\end{array}$ & $\mathrm{K}_{2} \mathrm{ZnCl}_{4}$ \\
\hline & Sylvite, syn & $\mathrm{KCl}$ \\
\hline & $\begin{array}{l}\text { Magnesium } \\
\text { ultraphosphate }\end{array}$ & $\mathrm{MgP}_{4} \mathrm{O}_{11}$ \\
\hline \multirow[t]{7}{*}{ Fraction 1} & Chlorocalcite, syn & $\mathrm{KCaCl}_{3}$ \\
\hline & $\begin{array}{l}\text { Calcium magnesium } \\
\text { chloride hydrate }\end{array}$ & $\mathrm{CaMg}_{2} \mathrm{Cl}_{6}\left(\mathrm{H}_{2} \mathrm{O}\right)_{12}$ \\
\hline & Calcium carbonate & $\mathrm{CaCO}_{3}$ \\
\hline & Calcium perchlorate & $\mathrm{Ca}\left(\mathrm{ClO}_{4}\right)_{2}$ \\
\hline & Anhydrite, syn & $\mathrm{CaSO}_{4}$ \\
\hline & Sylvite, syn & $\mathrm{KCl}$ \\
\hline & Dolomite & $\mathrm{CaMg}\left(\mathrm{CO}_{3}\right)_{2}$ \\
\hline
\end{tabular}




\begin{tabular}{lll} 
Fraction 2 & $\begin{array}{l}\text { Potassium zinc } \\
\text { / dioxane }\end{array}$ & $\mathbf{K}_{\mathbf{2}} \mathbf{Z n C l}_{\mathbf{4}}$ \\
& $\begin{array}{l}\text { tetrachloride } \\
\text { Zinc chloride } \\
\text { (tetragonal) }\end{array}$ & $\mathbf{Z n C l}_{2}$ \\
& \\
& Zinc chloride \\
(monoclinic) & $\mathbf{Z n C l}_{\mathbf{2}}$ \\
& \\
& Potassium chlorate & $\mathrm{KClO}_{3}$ \\
\hline
\end{tabular}

According to Pearson's HSAB principle, the catalytic solids generated from Zn metallophyte species led to modulation of the hard/soft ratio. The obtained catalytic solids could be distinguished according to three types of Lewis acid level. The purified N. caerulescens / A. vulneraria extract, called fraction 1, led to a Pearson's "Hard Lewis Acid" mixture, because $\mathrm{Mg}^{\mathrm{II}}, \mathrm{Ca}^{\mathrm{II}}, \mathrm{Al}^{\mathrm{III}}, \mathrm{Fe}^{\mathrm{III}}$ contributions represented $99.6 \%$ of the cationic mixture. Purified N. caerulescens / A. vulneraria extract, called fraction 2, led to a Pearson's "Borderline Lewis Acid" composition, with a mixture of borderline and soft Lewis acids $\left(\mathrm{Zn}^{\mathrm{II}}+\mathrm{Cd}^{\mathrm{II}}+\mathrm{Pb}^{\mathrm{II}}=64 \%\right)$. Crude extracts were constituted by miscellaneous cations with respect to Pearson's classification system.

The direct conversion of catalytic solid as zeolite like-materials had been investigated. According to Vanden Eynde and co-workers,[20] the methodology was based on a co-grinding; montmorillonite K10 was placed in a porcelain mortar and air-dried crude extract was then added and mixed with montmorillonite K10 using a pestle to obtain a homogeneous powder. The choice of conditions was also guided by the outcome of the experiment and was therefore considered realistic for an economic feasible process. The subsequent solid was characterized by XRF (Figure 4) and XRD (Figure 5). Fortunately, the mass percentage of $\mathrm{Zn}^{\mathrm{II}}$ was maintained, since the amount of chloride decreased. $\mathrm{K}_{2} \mathrm{ZnCl}_{4}$ was the observed sole zinc chloride (Table 3 ).

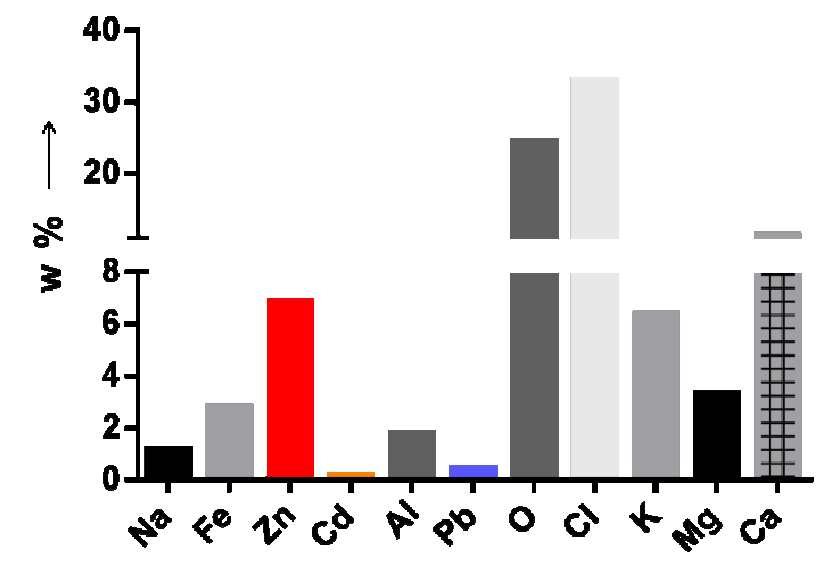

\section{A.vulneraria and N.caerulescens supported crude extract}

Fig. 4. Chemical composition of supported crude extract 


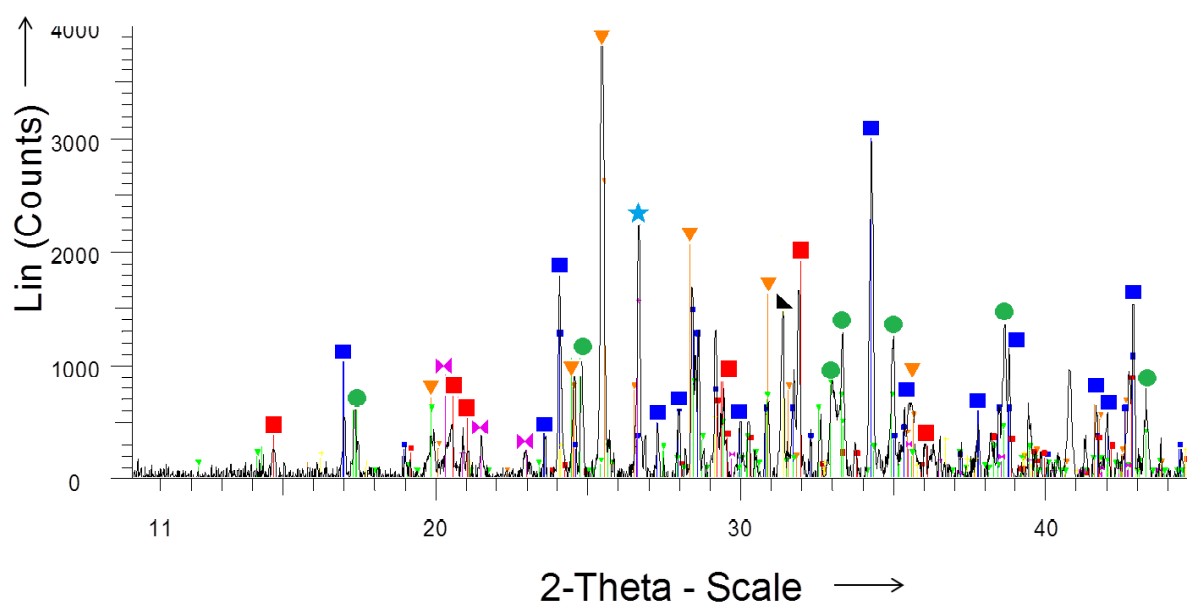

$\nabla$ Potassium Chlorate - $\mathrm{KClO} 4$

-Calcium Magnesium Silicate - Ca2MgSi2O7

- Chlorocalcite, syn [NR] - KCaCl3

$\star$ Quartz - SiO2

- Calcium Chloride Hydrate - $\mathrm{CaCl} 2(\mathrm{H} 2 \mathrm{O}) 2$ M Tridymite - $\mathrm{SiO} 2$

- Potassium Zinc Chlonide - $\mathrm{K} 2 \mathrm{ZnCl} 4$

Fig. 5. XRD pattern of supported crude extract

Table 3. XRD pattern of supported crude extract

\begin{tabular}{|c|c|c|}
\hline Fraction & Mineral & $\begin{array}{l}\text { Formula } \\
\text { (simplified) }\end{array}$ \\
\hline $\begin{array}{l}\text { Supported } \\
\text { crude on }\end{array}$ & $\begin{array}{l}\text { Calcium magnesium } \\
\text { chloride hydrate }\end{array}$ & $\mathrm{CaMg}_{2} \mathrm{Cl}_{6}\left(\mathrm{H}_{2} 0\right)_{12}$ \\
\hline montmorillonite & Anhydrite, syn & $\mathrm{CaSO}_{4}$ \\
\hline \multirow[t]{6}{*}{ K 10} & $\begin{array}{l}\text { Potassium zinc } \\
\text { tetrachloride }\end{array}$ & $\mathrm{K}_{2} \mathrm{ZnCl}_{4}$ \\
\hline & Potassium perchlorate & $\mathrm{KClO}_{4}$ \\
\hline & Chlorocalcite, hydrate & $\mathrm{CaCl}_{2}\left(\mathrm{H}_{2} \mathrm{O}\right)_{2}$ \\
\hline & $\begin{array}{l}\text { Calcium magnesium } \\
\text { silicate }\end{array}$ & $\mathrm{Ca}_{2} \mathrm{MgSi}_{2} \mathrm{O}_{7}$ \\
\hline & Quartz & $\mathrm{SiO}_{2}$ \\
\hline & Tridymite & $\mathrm{SiO}_{2}$ \\
\hline
\end{tabular}




\subsection{Characterization of the Lewis acidity by pyridine adsorption}

Pyridine is widely used as a probe molecule for determination of Lewis acidity on solid acids, by monitoring the bands in the range of $1400-1650 \mathrm{~cm}^{-1}$ arising from its ring vibration modes.[21, 22] Infrared spectra of pyridine adsorbed on crude fraction were recorded at $25^{\circ} \mathrm{C}$ and $150^{\circ} \mathrm{C}$ in order to distinguish frequencies of physisorbed pyridine from frequencies of pyridine coordinated to Lewis sites (Figure 6).

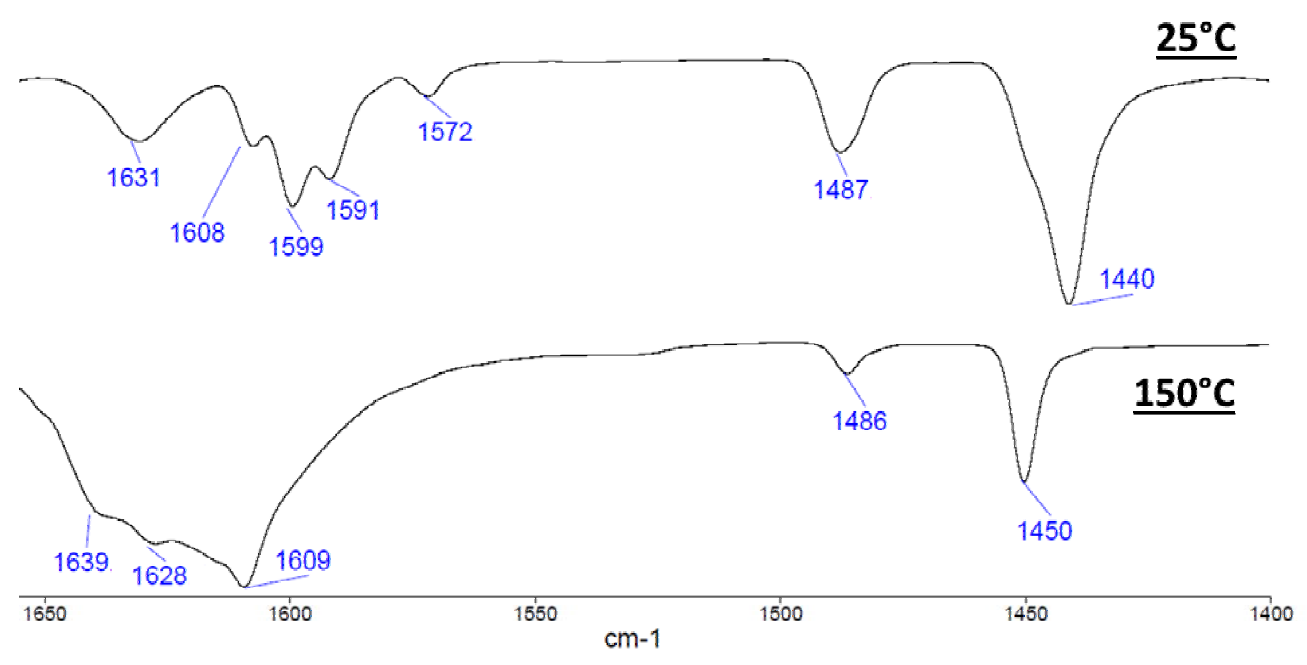

Fig. 6. IR spectra of adsorbed pyridine on crude extract taken following brief outgassing at the indicated temperatures

Figure 6 shows that a band at $1440 \mathrm{~cm}^{-1}$ observed at $25^{\circ} \mathrm{C}$ disappeared after outgassing at $150^{\circ} \mathrm{C}$, and could thus be attributed to physisorbed, weakly bonded, pyridine.[21] In the same range, a band at $1450 \mathrm{~cm}^{-1}$ was observed at $150^{\circ} \mathrm{C}$. This band was characteristic of pyridine, which was still strongly bonded at this temperature, by coordination to Lewis acid sites.[22] It was the first indication of the extract Lewis acidity.

The decrease of the band intensity at $1486-1487 \mathrm{~cm}^{-1}$ is more delicate to explain. It could be attributed to physisorbed pyridine, as the intensity was strongly reduced after heating.

Looking at bands in the $1590-1640 \mathrm{~cm}^{-1}$ range, the band at $1599 \mathrm{~cm}^{-1}$ observed at $25^{\circ} \mathrm{C}$ disappeared at $150^{\circ} \mathrm{C}$, this one being characteristic of hydrogen-bonded pyridine.[21] On the other hand, several bands were observed in the $1600-1640 \mathrm{~cm}^{-1}$ range, with small variations in frequencies, depending on outgassing temperature (1608 and $1631 \mathrm{~cm}^{-1}$ at $25^{\circ} \mathrm{C} ; 1609,1628$ and $1639 \mathrm{~cm}^{-1}$ at $\left.150^{\circ} \mathrm{C}\right)$. The continued existence of bands in this range, in spite of heating at elevated temperature, indicated the presence of strongly bonded pyridine. In previous studies, these bands had been attributed to pyridine coordinated to Lewis acid sites. The occurrence of these bands at different frequencies in this range may account for the involvement of different types of Lewis acid sites.[22] This hypothesis was supported by the previous X-ray data (Table 2), highlighting the presence of different Lewis acids in the extract. 


\subsection{Synthetic applications of ecological catalysts in the transformations of biomolecules}

Figure 7 demonstrates the synthetic utility of these ecological catalytic systems through multifunctional biomolecule synthesis.

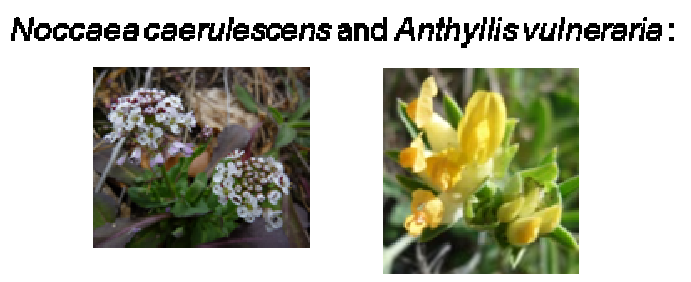

Zn hyperaccumulator plants promising in ecological catalysis

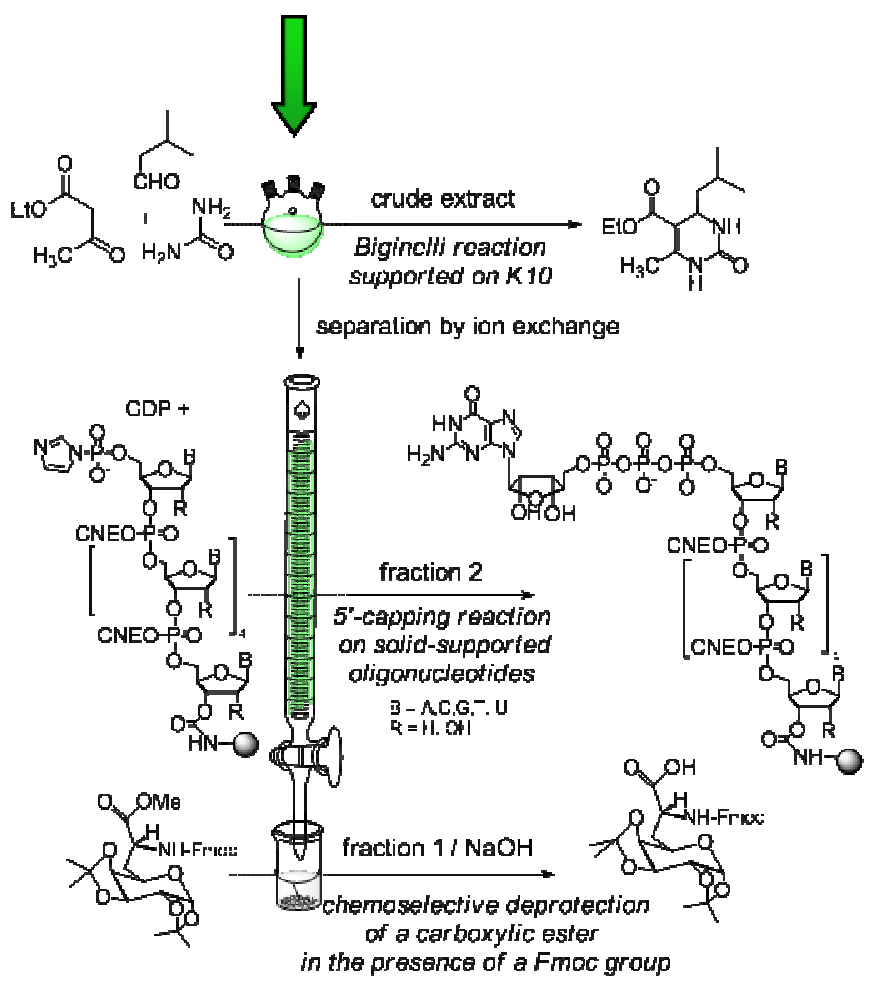

Fig. 7. Synthetic applications of ecological catalysts in the transformations of biomolecules

\subsubsection{Dihydropyrimidinone synthesis}

The first example illustrated the non-conventional catalytic activity of the crude mixture derived from $N$. caerulescens and A. vulneraria in supported multicomponent reactions. Biginelli reaction was an interesting example, because this reaction led to dihydropyrimidinone heterocycles, starting from aldehyde, $\mathrm{CH}$-acidic carbonyl component and urea-type molecule.[23-25] Recently dihydropyrimidinones have been the object of an increased interest, as these molecules exhibit exciting biological features.[26, 27] Among the pharmacological reported properties, calcium channel modulators, $\alpha_{1 \mathrm{a}}$ adrenoreceptor-selective antagonists and compounds targeting the mitotic machinery can be cited as examples. Since the discovery of this reaction by Pietro Biginelli in 1893[28] the yield of this reaction has been improved especially by the use of Lewis acid catalysts.[24, 25] Despite important progress achieved, yields are still low when aliphatic aldehydes are used, probably because of self aldol condensation, a side reaction which does not occur when aromatic aldehydes are used.[29-31] 
However, when using Green Lewis Acid Catalyst derived from Zn metallophytes in this reaction, excellent yields were obtained, even with aliphatic aldehydes as building blocks. The yield was increased in comparison with others published catalytic systems [32-36] as shown in Table 4, illustrating the synthesis of 5ethoxycarbonyl-4-isobutyl-6-methyl-3,4-dihydropyrimidin-2(1H)-one 4 (Scheme 1).

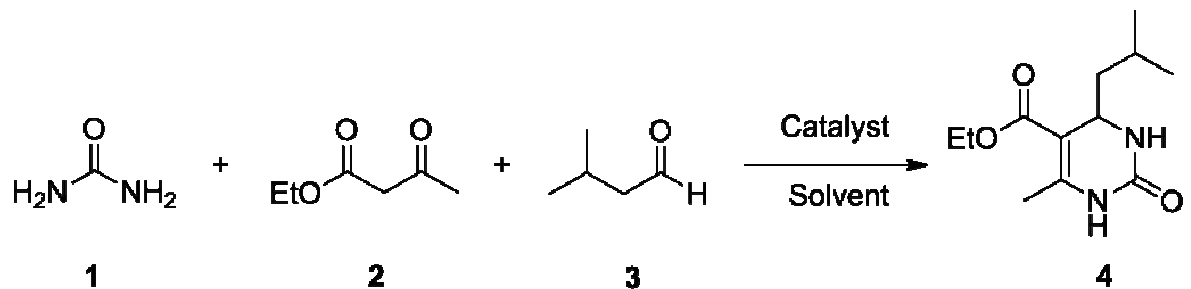

Scheme 1. Synthesis of dihydropyrimidinone 4 with various catalysts (see Table 4)

Table 4. Activity comparison of different catalysts in the Biginelli reaction involving urea 1, ethyl acetoacetate 2 and isovaleraldehyde $\mathbf{3}$.

\begin{tabular}{|c|c|c|c|c|}
\hline Catalyst & Solvent & Time & $\begin{array}{l}\text { Yield } \\
(\%)\end{array}$ & Reference \\
\hline $\begin{array}{l}\text { Zn Green Lewis } \\
\text { Acid Catalyst } \\
\text { supported on } \\
\text { K10/HCl }\end{array}$ & EtOH $95 \%$ & $5 \mathrm{~h}$ & 91 & this work \\
\hline $\begin{array}{l}\text { Ionic liquid } \\
{[\mathrm{bmim}] \mathrm{Cl} \cdot 2 \mathrm{AlCl}_{3}}\end{array}$ & $\begin{array}{l}\text { Ionic liquid } \\
{[\mathrm{bmim}] \mathrm{Cl} \cdot 2 \mathrm{AlCl}_{3}}\end{array}$ & $1 \mathrm{~h} 15$ & 87 & {$[35]$} \\
\hline $\begin{array}{l}\text { Montmorillonite } \\
\text { KSF }\end{array}$ & $\begin{array}{l}\text { Solvent free } \\
\text { (microwave } \\
\text { irradiation) }\end{array}$ & $16 \mathrm{~min}$ & 85 & {$[36]$} \\
\hline Sulfated tungstate & Solvent free & $1 \mathrm{~h} 05$ & 65 & {$[34]$} \\
\hline $\begin{array}{l}\text { Proline-based } \\
\text { organocatalyst, } \\
\text { pentafluorobenzoic } \\
\text { acid, } \\
\mathrm{Ph}_{3} \mathrm{CNH}_{3}{ }^{+} \mathrm{CF}_{3} \mathrm{COO}^{-}\end{array}$ & $\begin{array}{l}\text { THF/dioxane } \\
(1: 1)\end{array}$ & $96 \mathrm{~h}$ & 60 & {$[33]$} \\
\hline $\mathrm{ZnI}_{2}, 300 \mathrm{MPa}$ & acetonitrile & $4 \mathrm{~h}$ & 55 & {$[32]$} \\
\hline
\end{tabular}

As it was mentioned by Mitra and coworkers that montmorillonite KSF clay could catalyze Biginelli reaction under microwave irradiation,[36] blank reaction was performed with the sole support, montmorillonite K10, and hydrochloric acid, without Green Lewis Acid Catalyst (3 drops of concentrated hydrochloric acid were added in order to ensure the complete solubility of potentially formed bisureide, as previously reported[37]). As shown in Table 5, when the reaction was performed with the sole montmorillonite $\mathrm{K} 10 / \mathrm{HCl}$, the yield was only $67 \%$, which proves that the high yield obtained with supported Zn Green Lewis Acid Catalyst was due to the Lewis acids provided by the hyperaccumulating plants. Encouraged by this result, we tried the reaction with other aliphatic and aromatic aldehydes (Scheme 2 and Table 5). Again, good yields of dihydropyrimidinones were obtained and, each time, they were superior to the yields with sole montmorillonite $\mathrm{K} 10 / \mathrm{HCl}$. Furthermore, the 
Zn Green Lewis Acid Catalyst was recycled by filtration, washing with ethanol, and reactivation by heating $\left(150^{\circ} \mathrm{C}, 5 \mathrm{~h}\right)$. The yield of dihydropyrimidinone 4 remained basically unchanged ( $88 \%$, entry 4$)$, showing that the $\mathrm{Zn}$ Green Lewis Acid Catalyst could be reused after recycling.

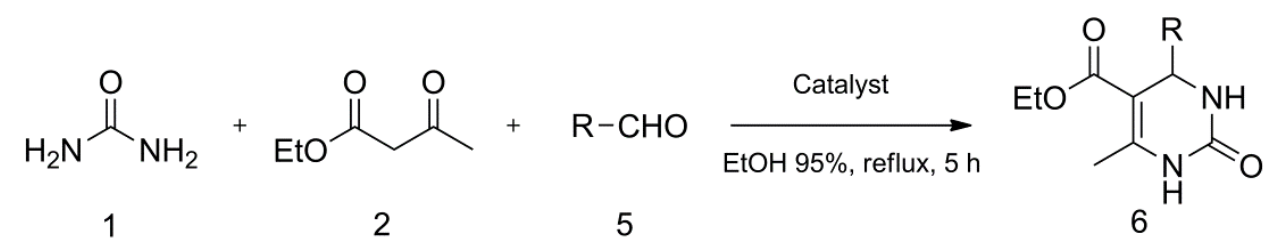

Scheme 2. Synthesis of various dihydropyrimidinones with Zn Green Lewis Acid Catalyst or with sole montmorillonite $\mathrm{K} 10 / \mathrm{HCl}$ (see Table 5)

Table 5. Conditions of synthesis and isolated yields

\begin{tabular}{|c|c|c|c|}
\hline Entry & $\mathbf{R}$ & Catalyst & Yield (\%) \\
\hline 1 & $\left(\mathrm{CH}_{3}\right)_{2} \mathrm{CHCH}_{2}$ & $\begin{array}{l}\text { Zn Green Lewis Acid Catalyst supported on } \\
\mathrm{K} 10 / \mathrm{HCl}\end{array}$ & 91 \\
\hline 2 & $\left(\mathrm{CH}_{3}\right)_{2} \mathrm{CHCH}_{2}$ & $\mathrm{~K} 10 / \mathrm{HCl}^{a}$ & 67 \\
\hline 3 & $\left(\mathrm{CH}_{3}\right)_{2} \mathrm{CHCH}_{2}$ & $\mathrm{~K} 10$ & 58 \\
\hline 4 & $\left(\mathrm{CH}_{3}\right)_{2} \mathrm{CHCH}_{2}$ & $\begin{array}{l}\text { Recycled }^{b} \mathrm{Zn} \text { Green Lewis Acid Catalyst } \\
\text { supported on } \mathrm{K} 10 / \mathrm{HCl}\end{array}$ & 88 \\
\hline 5 & $\mathrm{CH}_{3} \mathrm{CH}_{2}$ & $\begin{array}{l}\text { Zn Green Lewis Acid Catalyst supported on } \\
\mathrm{K} 10 / \mathrm{HCl}\end{array}$ & 93 \\
\hline 6 & $\mathrm{CH}_{3} \mathrm{CH}_{2}$ & $\mathrm{~K} 10 / \mathrm{HCl}$ & 54 \\
\hline 7 & $\mathrm{CH}_{3} \mathrm{CH}_{2} \mathrm{CH}_{2}$ & $\begin{array}{l}\text { Zn Green Lewis Acid Catalyst supported on } \\
\mathrm{K} 10 / \mathrm{HCl}\end{array}$ & 90 \\
\hline 8 & $\mathrm{CH}_{3} \mathrm{CH}_{2} \mathrm{CH}_{2}$ & $\mathrm{~K} 10 / \mathrm{HCl}$ & 78 \\
\hline 9 & $\mathrm{Ph}$ & $\begin{array}{l}\text { Zn Green Lewis Acid Catalyst supported on } \\
\mathrm{K} 10 / \mathrm{HCl}\end{array}$ & 87 \\
\hline 10 & $\mathrm{Ph}$ & $\mathrm{K} 10 / \mathrm{HCl}$ & 53 \\
\hline 11 & $3-\mathrm{BrC}_{6} \mathrm{H}_{4}$ & $\begin{array}{l}\text { Zn Green Lewis Acid Catalyst supported on } \\
\mathrm{K} 10 / \mathrm{HCl}\end{array}$ & 96 \\
\hline 12 & $3-\mathrm{BrC}_{6} \mathrm{H}_{4}$ & $\mathrm{~K} 10 / \mathrm{HCl}$ & 74 \\
\hline
\end{tabular}

${ }^{a}$ The mass of montmorillonite K10 et the volume of hydrochloric acid were the same as those used in the preparation of $\mathrm{Zn}$ Green Lewis Acid Catalyst supported on $\mathrm{K} 10 / \mathrm{HCl}$.

${ }^{b}$ Catalyst recycled one time.

The experimental conditions using Zn Green Lewis acid Catalyst are consistent with the principles of Green Chemistry, especially because the solvent is non-toxic, cheap, and may be biosourced.

In order to explain the high activity of $\mathrm{Zn}$ Green Lewis Acid Catalyst in this transformation, we propose that cooperative effects exist between the different Lewis acids of our ecological catalysts. The most commonly accepted mechanism for the Biginelli reaction, proposed by Kappe in 1997, involves the formation of a $N-$ acyliminium ion intermediate.[38] In a similar mechanism, Hu and coworkers suggested that Lewis acid can interact with three distinct sites during the reaction.[39] Following this mechanism, Lewis acid acts by coordination to the urea oxygen and to the nitrogen atom of the acyl imine 7, stabilizing the intermediate (Scheme 3). Moreover, when 1,3-dicarbonyl component is used as $\mathrm{CH}$-acidic carbonyl component, chelation of the Lewis acid should stabilize the enol tautomer. Using a co-catalytic system formed of two Lewis acids, $\mathrm{BF}_{3} . \mathrm{OEt}_{2}$ and $\mathrm{Cu}(\mathrm{OAc})_{2}, \mathrm{Hu}$ and coworkers suggested that both Lewis acids activate different sites according to 
their highest affinity. That is why we propose that the Zn Green Lewis Acid Catalyst should act in the same way: as this catalyst is a mixture of various transition metal salts, with different Lewis acidity, each metal salt should coordinate to one of the three sites for which it would have the best affinity. As each reaction site has a proper Lewis basicity, it should coordinate preferentially to one kind of Lewis acid, following principles of Hard-Soft Acid-Base theory.[40-43] Due to the binding of each reaction site to its "optimal" Lewis acid partner, the reaction should be better catalyzed by a polymetallic catalyst, which offers different acid sites.

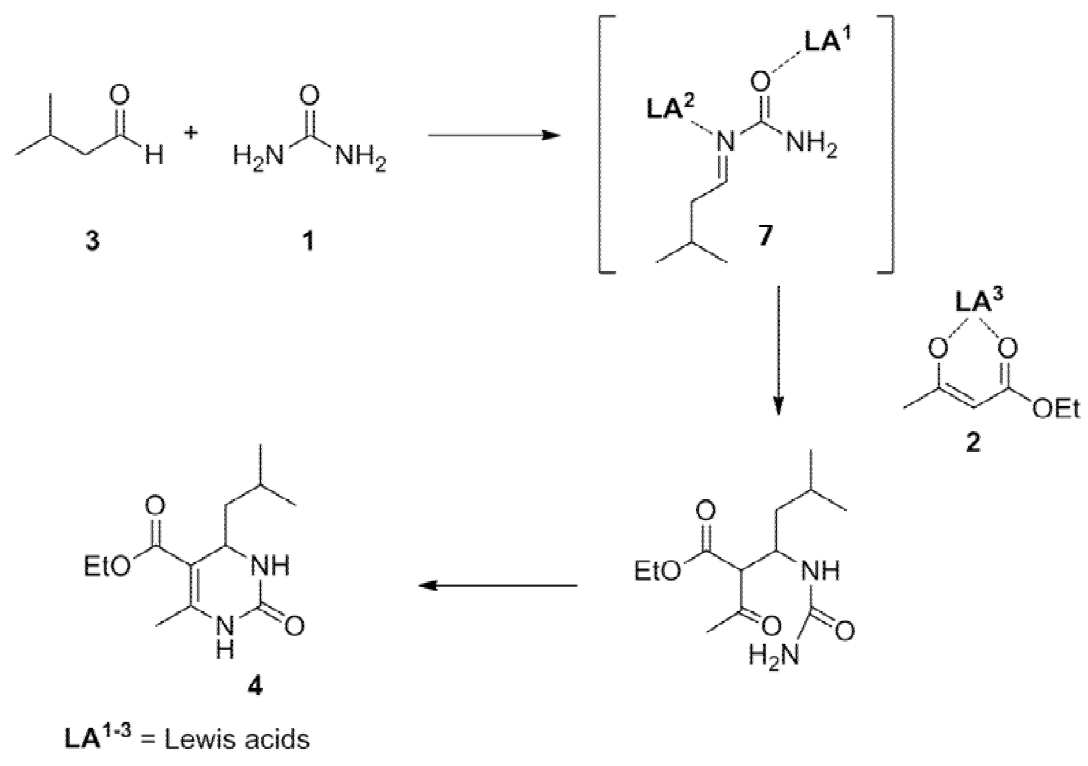

Scheme 3. Co-catalysis of the Biginelli reaction with different Lewis acids

This synergetic effect could thus explain the high activity of the Zn Green Lewis acid in the Biginelli reaction with aliphatic aldehydes, giving poor yields with classical catalysts. This hypothesis is sustained by other published examples of Lewis acid co-catalysis in the Biginelli reaction, leading to excellent yields.[44, 45] However, a supplementary explanation about the power of the ecological catalyst for aliphatic aldehydes can be highlighted. As shown in Figure 1, the major species of $\mathrm{Zn}^{\mathrm{II}}$ is $\mathrm{K}_{2} \mathrm{ZnCl}_{4}$. That supposes a progressive release of $\mathrm{ZnCl}_{2}$ in solution, which limits the concurrent enolization of aldehyde.

\subsubsection{Chemoselective hydrolysis in peptide chemistry}

Another stimulating example of the activity of the Green Lewis Acid Catalyst concerns chemoselective hydrolysis. Peptide synthesis requires the use of orthogonal protecting groups, to allow modification of selected sites without reaction of other functions of the molecule during the synthesis.[46-48] The 9-

fluorenylmethoxycarbonyl group (Fmoc) is a base-labile $\alpha$-amino protecting group widely used in peptide synthesis.[49, 50] When carboxyl-protecting groups are involved during a synthesis, the choice of using Fmoc as $\alpha$-amino protecting group presupposes that these carboxyl-protecting groups should not be cleaved during Fmoc deprotection. This is generally avoided by the use of orthogonal carboxyl-protecting groups, such as tert-butyl, allyloxycarbonyl or benzyl, resisting to Fmoc cleavage conditions.[48] An alternative had been proposed by Pascal and Sola, showing that the use of $\mathrm{CaCl}_{2}$ with $\mathrm{NaOH}$ allowed the selective basic cleavage of carboxylic ester function in the presence of Fmoc group.[51] The authors proposed that this chemoselective deprotection was due to two effects: first, "stabilization of the negatively charged tetrahedral transition state by coordination 
with $\mathrm{Ca}^{2+}$ facilitating ester hydrolysis", second, "reduction of the hydroxide ion concentration due to the formation and incomplete dissociation of calcium hydroxide", in favour of hydrolysis of the ester and limiting $\beta$ elimination of Fmoc group. Due to the high content of calcium of fraction 1 of the Green Lewis Acid Catalyst, we formulated the hypothesis that this catalytic fraction would be an excellent alternative to Pascal and Sola conditions. The eluted first fraction of crude ecological catalyst, highly enriched in $\mathrm{CaCl}_{2}$, was concentrated. The controlled addition of $\mathrm{NaOH}(1 \mathrm{M})$ until $\mathrm{pH} 4$ allowed the chemoselective hydrolysis of the methyl ester of 6,7dideoxy-1,2 :3,4-di- $O$-isopropyldine-7-[(9-flurenylmethoxy carbonyl)amino]-D-glycero- $\alpha$-D-galactooctopyranuronic methyl ester $\mathbf{8}$, without the cleavage of the base labile Fmoc. The expected galactosyl aminoacid 9 was obtained with $82 \%$ yield (Scheme 4 ).

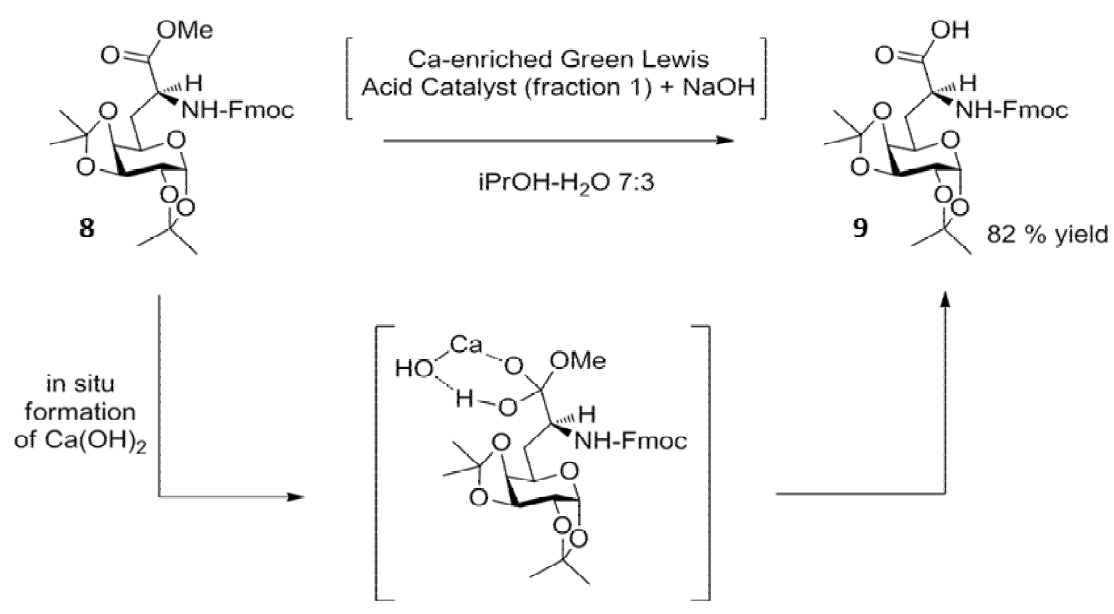

Scheme 4. Selective deprotection of carboxyl group without the cleavage of Fmoc with Ca-enriched Green Lewis Acid Catalyst (fraction 1).

In order to ensure that this methodology is adapted to substrates different of sugars, two methyl esters of amino acid-based Fmoc derivatives were tested successfully (Table 6).

Table 6. Deprotection of carboxyl group without the cleavage of Fmoc of amino acid derivatives

\begin{tabular}{lllcc}
\hline Entry & Substrate & Catalyst $^{a}$ & Time $^{\text {Yield }}(\boldsymbol{\%})$ \\
\hline 1 & Fmoc-Gly-OMe & $\begin{array}{l}\text { Ca-enriched Green Lewis Acid Catalyst } \\
\text { (fraction 1) }\end{array}$ & $1 \mathrm{~h}$ & 84 \\
2 & Fmoc-Gly-Phe-Pro-OMe & $\begin{array}{l}\text { Ca-enriched Green Lewis Acid Catalyst } \\
\text { (fraction 1) }\end{array}$ & $6 \mathrm{~h}$ & 71 \\
\hline
\end{tabular}

${ }^{a}$ The mass of catalyst is estimated following ICP-MS dosing, to correspond to 2.0 equivalents of $\mathrm{Ca}$ (II). Reaction conducted in $15 \mathrm{~mL}$ of a mixture of isopropanol/water 7/3 (v/v), at room temperature.

${ }^{b}$ Isolated yield. 
The good yields obtained with these substrates confirm the interest of this method in peptide chemistry, for selective deprotection of methyl esters.

\subsubsection{Synthesis of 5'-capped oligonucleotides}

Convenient access and availability of large quantities of capped DNA and RNA are of great interest for biologists for structural and mechanistic studies of complexes with RNA capping enzymes.[52-55]

The need to develop an efficient method to functionalize RNA at their 5'-end with the cap structures guanosyl triphosphate (Gppp) attracted our attention and led us to study the performance of our ecological catalysts in the transformation. Starting our studies with a DNA homosequence as a model, we found that the $\mathrm{ZnCl}_{2}$ enriched solid (fraction 2), was an excellent catalyst for the coupling reaction between the guanosine-5'-diphosphate (GDP) bis(tetrabutylammonium) salt $\mathbf{1 0}$ and the 5'-phosphorimidazolidate derived from a solid-supported hexathymidylate $\left(\mathrm{T}_{6}-\mathrm{CPG}\right) \mathbf{1 1}$ (Scheme 5 ). The obtained yield for the synthesis of 5 '-terminal capped oligonucleotides $\mathrm{GpppT}_{6} 12(65 \%)$ was better than pure $\mathrm{ZnCl}_{2}$ (55\%). Therefore a synergetic effect might exist between the present Lewis acids which improved catalytic performance, when a mixture of borderline and soft Lewis acids was made (fraction 2).

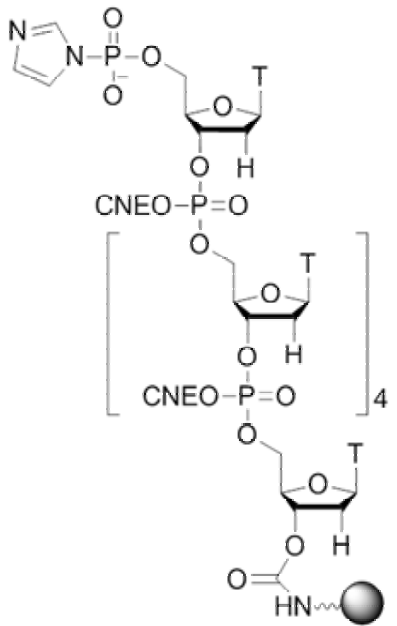

11

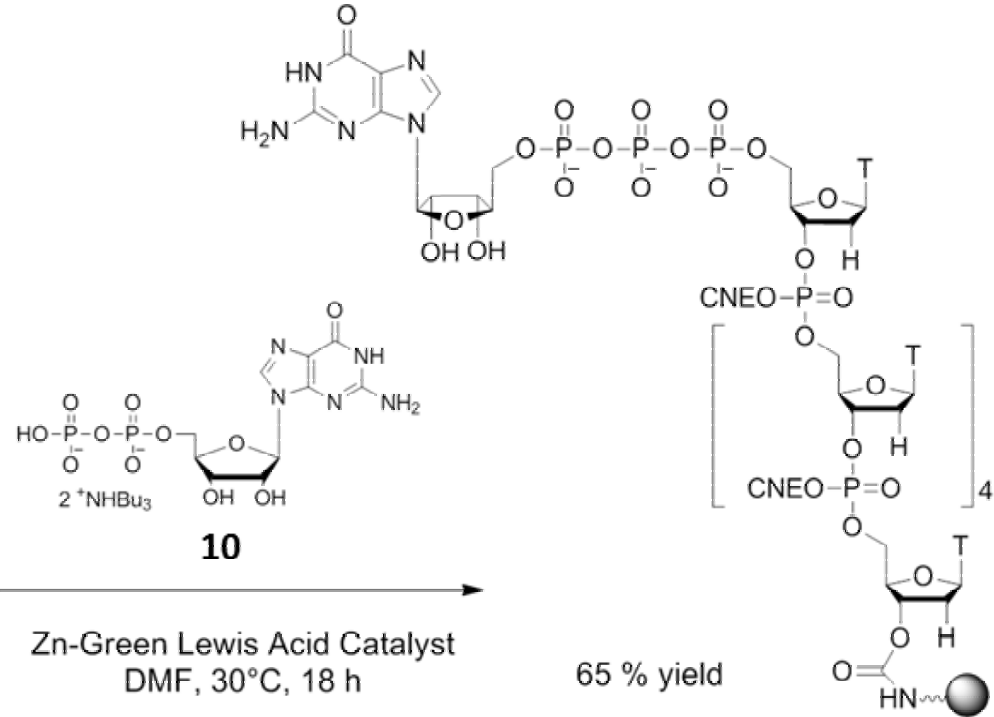

12

Scheme 5. Coupling reaction between GDP 10 and $\mathrm{T}_{6}-\mathrm{CPG} 11$ catalyzed by $\mathrm{Zn}$-enriched Green Lewis Acid Catalyst (fraction 2)

These observations showed again that a combination of different metal halides led to more active systems than individual components. The result is consistent with the activation of three basic Lewis centres during the coupling: phosphate groups of GDP, imidazole and phosphate moiety of phosphoroimidazolidate (Scheme 6). This adjustment of coordination by relative affinity is a real advantage of the Ecological Catalysis. 


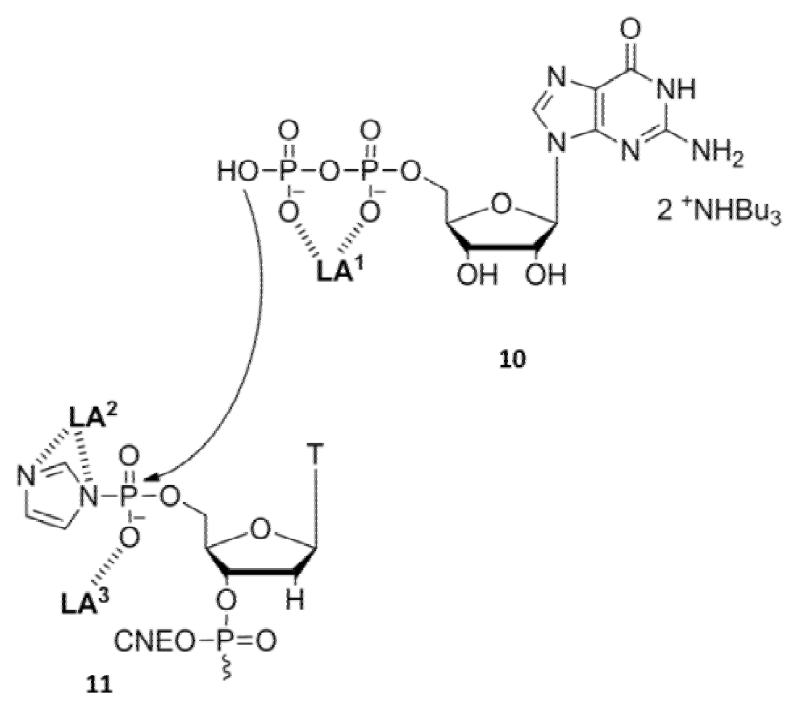

Scheme 6. Activation of basic Lewis centres of reactants by different Lewis acids of $\mathrm{Zn}$-enriched Green Lewis Acid Catalyst

\section{Conclusion}

The potential utility of this new plant-inspired catalysis was clearly demonstrated by its application to the synthesis of complex heterocycles, glycosyl aminoacid and 5'-capped DNA and RNA. Ecological catalysts derived from metallophytes provided improved catalyst performances compared to the most known catalysts. The wide variety of reactions that are catalyzed by ecological catalysts, and the ease of preparation of such catalysts create manifold opportunities for the development of catalytic processes. The development of $\mathrm{Zn}$ hyperaccumulating plants for organic synthesis leads to innovative and fascinating plant-based materials. They represent a more sustainable and promising system and suggest that sustainable chemistry and performance can be combined. Other novel developments of Ecological Catalysis are certain to emerge in the future.

\section{ACKNOWLEDGMENTS}

The authors would like to thank ANR (11ECOT 011 01), ADEME, FEDER program for financial supports.

\section{REFERENCES}

P. Anastas, J.C. Warner, Green Chemistry: Theory and Practice, Oxford University Press, Oxford, 1998. 
[2] N. Winterton, Green Chemistry 3 (2001) G73-G81.

[3] R.A. Sheldon, Chemical Society Reviews 41 (2012) 1437-1451.

[4] R.A. Sheldon, I. Arends, U. Hanefeld, in: P. Serpe, C. Philippot (Eds.), Green Chemistry and Catalysis, Wiley-VCH, Weinheim, 2008 .

[5] V. Polshettiwar, J.-M. Basset, D. Astruc, ChemSusChem 5 (2012) 1-212 and references cited therein.

[6] D.K. Kyriacou, D.A. Jannakoudakis, Electrocatalysis for organic synthesis, John Wiley \& Sons, New-York, 1986.

[7] K. Drauz, H. Groger, O. May, Enzyme catalysis in organic synthesis, $3^{\text {rd }}$ Ed. ed., Wiley-VCH, Weinheim, 2012.

[8] D.J. Glass, in: B.D. Ensley, I. Raskin (Eds.), Phytoremediation of Toxic Metals: Using Plants to Clean up the Environment, John Wiley \& Sons, New-York, 1999, pp. 15-32.

[9] R.L. Chaney, Y.-M. Li, S.L. Brown, F.A. Homer, M. Malik, J.S. Angle, A.J.M. Baker, R.D. Reeves, M. Chin, in: N. Terry (Ed.), Phytoremediation of Contaminated Soil and Water, CRC Press, 2000, p. 408.

[10] Y.-M. Li, R. Chaney, E. Brewer, R. Roseberg, J.S. Angle, A. Baker, R. Reeves, J. Nelkin, Plant and Soil 249 (2003) $107-115$.

[11] M. Mench, N. Lepp, V. Bert, J.-P. Schwitzguébel, S. Gawronski, P. Schröder, J. Vangronsveld, Journal of Soils and Sediments 10 (2010) 1039-1070.

[12] C. Grison, J. Escarré, WO2011/064462A1; PCT/FR2009/052312 (2011).

[13] C. Grison, J. Escarré, WO2011/064487A1; PCT/FR2010/052451; CA2781832-A1; EP2504096-A1 (2011).

[14] G. Losfeld, V. Escande, P. Vidal de La Blache, L. L'Huillier, C. Grison, Catalysis Today 189 (2012) $111-116$.

[15] G. Losfeld, V. Escande, T. Jaffré, L. L’Huillier, C. Grison, Chemosphere 89 (2012) 907-910.

[16] G. Losfeld, P. Vidal de La Blache, V. Escande, C. Grison, Green Chemistry Letters and Reviews (2012) 1-6.

[17] Y. Thillier, E. Decroly, F. Morvan, B. Canard, J.-J. Vasseur, F. Debart, RNA 18 (2012) 856-868.

[18] R. Fezei, H. Hammi, A. M'nif, Chemical Engineering Research and Design 89 (2011) 367-372.

[19] J. Burgess, R.H. Prince, in: R.B. King (Ed.), Encyclopedia of Inorganic Chemistry, 2nd ed., John Wiley \& sons, New-York, 2005, pp. 5928-5954.

[20] J.J. Vanden Eynde, A. Mayence, Y. Van Haverbeke, Tetrahedron Letters 36 (1995) 3133-3136.

[21] E.P. Parry, Journal of Catalysis 2 (1963) 371-379.

[22] M.I. Zaki, M.A. Hasan, F.A. Al-Sagheer, L. Pasupulety, Colloids and Surfaces A: Physicochemical and Engineering Aspects 190 (2001) 261-274

[23] C.O. Kappe, Accounts of Chemical Research 33 (2000) 879-888.

[24] C.O. Kappe, A. Stadler, Organic Reactions, John Wiley \& Sons, Inc., 2004

[25] Suresh, J.S. Sandhu, Arkivoc i (2012) 66-133.

[26] C.O. Kappe, European Journal of Medicinal Chemistry 35 (2000) 1043-1052.

[27] C.O. Kappe, O.V. Shishkin, G. Uray, P. Verdino, Tetrahedron 56 (2000) 1859-1862.

[28] P. Biginelli, Gazzetta Chimica Italiana 23 (1893) 360-413.

[29] J. Lu, Y. Bai, Synthesis 2002 (2002) 0466-0470.

[30] Y.-1. Zhu, S.-1. Huang, Y.-j. Pan, European Journal of Organic Chemistry 2005 (2005) 2354-2367.

[31] E. Rafiee, F. Shahbazi, Journal of Molecular Catalysis A: Chemical 250 (2006) 57-61.

[32] G. Jenner, Tetrahedron Letters 45 (2004) 6195-6198.

[33] S. Saha, J.N. Moorthy, The Journal of Organic Chemistry 76 (2011) 396-402.

[34] S.D. Salim, K.G. Akamanchi, Catalysis Communications 12 (2011) 1153-1156.

[35] S.S. Bahekar, S.A. Kotharkar, D.B. Shinde, Mendeleev Communications 14 (2004) 210-212.

[36] A.K. Mitra, K. Banerjee, Synlett 2003 (2003) 1509-1511.

[37] R. Pérez, T. Beryozkina, O.I. Zbruyev, W. Haas, C.O. Kappe, Journal of Combinatorial Chemistry 4 (2002) 501-510.

[38] C.O. Kappe, The Journal of Organic Chemistry 62 (1997) 7201-7204.

[39] E.H. Hu, D.R. Sidler, U.-H. Dolling, The Journal of Organic Chemistry 63 (1998) 3454-3457.

[40] R.G. Pearson, Journal of the American Chemical Society 85 (1963) 3533-3539.

[41] T.-L. Ho, Chemical Reviews 75 (1975) 1-20.

[42] R.G. Pearson, Journal of Chemical Education 64 (1987) 561.

[43] P.W. Ayers, R.G. Parr, R.G. Pearson, The Journal of Chemical Physics 124 (2006) 194107.

[44] A. Kumar, R.A. Maurya, Journal of Molecular Catalysis A: Chemical 272 (2007) 53-56

[45] M. Shailaja, A. Manjula, B.V. Rao, N. Parvathi, Synthetic Communications 34 (2004) 1559-1564.

[46] V.V. Sureshbabu, N. Narendra, Amino Acids, Peptides and Proteins in Organic Chemistry, Wiley-VCH Verlag GmbH \& Co. KGaA, 2011, pp. 1-97.

[47] N. Sewald, H.-D. Jakubke, Peptides: Chemistry and Biology, Wiley-VCH Verlag GmbH \& Co. KGaA, 2009, pp. 175-315.

[48] A. Isidro-Llobet, M. Alvarez, F. Albericio, Chemical Reviews 109 (2009) 2455-2504.

[49] L.A. Carpino, G.Y. Han, Journal of the American Chemical Society 92 (1970) 5748-5749.

[50] L.A. Carpino, G.Y. Han, The Journal of Organic Chemistry 37 (1972) 3404-3409.

[51] R. Pascal, R. Sola, Tetrahedron Letters 39 (1998) 5031-5034.

[52] S. Shuman, Progress in Nucleic Acid Research and Molecular Biology, Academic Press, 2000, pp. 1-40.

[53] A.E. Hodel, P.D. Gerson, F.A. Quiocho, Molecular Cell 1 (1998) 443-447.

[54] A.J. Shatkin, Cell 9 (1976) 645-653.

[55] R. Zust, L. Cervantes-Barragan, M. Habjan, R. Maier, B.W. Neuman, J. Ziebuhr, K.J. Szretter, S.C. Baker, W. Barchet, M.S. Diamond, S.G. Siddell, B. Ludewig, V. Thiel, Nat Immunol 12 (2011) 137-143. 